\title{
PENGARUH LAMA WAKTU MORDANTING TERHADAP KETUAAN WARNA DAN KEKUATAN TARIK KAIN MORI DALAM PROSES PEWARNAAN DENGAN ZAT PEWARNA SABUT KELAPA
}

\author{
Esther Mayliana
}

\begin{abstract}
ABSTRAK
Penelitian ini memiliki tujuan untuk mengetahui (1) ketuaan warna kain mori pada pewarnaan mengunakan zat pewarna sabut kelapa dengan lama waktu mordanting 8 jam, 12 jam dan16 jam, (2) kekuatan tarik kain mori pada pewarnaan menggunakan zat pewarna sabut kelapa dengan lama mornadanting 8 jam, 12 jam dan 16 jam, (3) pengaruh lama waktu mordanting 8 jam, 12 jam dan 16 jam terhadap ketuaan warna (4) pengaruh lama waktu mordanting 8 jam, 12 jam, dan 16 jam terhadap kekuatan tarik kain.

Jenis penelitian yang digunakan adalah eksperimen. Sabut kelapa dimanfaatkan sebagai bahan pewarna alam dengan mordan soda abu dan tawas. Variabel bebas penelitian ini adalah lama waktu mordanting ( $8 \mathrm{jam}, 12 \mathrm{jam}, 16 \mathrm{jam}$ ), dengan 12 jam sebagai kontrol. Variabel terikatnya adalah ketuaan warna dan kekuatan tarik kain mori. Unit eksperimen berupa kain mori primissima merek kereta kencana. Rancangan acak lengkap digunakan pada teknik penentuan letak pengambilan sampel uji. Ketuaan warna diuji dengan Sepectrophotometer, ukuran sampel uji $5 \mathrm{~cm} \times 5 \mathrm{~cm}$. Kekuatan tarik uji dengan cara jalur potong (Strip test), tiap ukuran sampel uji $2,5 \mathrm{~cm} \times 30 \mathrm{~cm}$ dan diuji menggunakan alat Tenso Lab. Normalitas dan Homogenitas diuji dengan Chi Kuadrat dan C-Cochran. Data dianalisis dengan menggunakan Analisis Varians satu jalur.

Rerata hasil penelitian nilai ketuaan warna kain mori yang dimordanting 8 jam adalah 1,015, mordanting 12 jam adalah 1,067 dan mordanting 16 jam adalah 1,033, dengan hasil warna coklat muda untuk ketiga perlakuan. Rerata kekuatan tarik kain mori yang telah dimordanting 8 jam adalah 20,680, mordanting 12 jam 10,019, dan mordanting 16 jam 21,119. Analisa data menunjukkan hasil: (1) tidak ada pengaruh lama waktu mordanting (8 jam, 12 jam, 16 jam) terhadap ketuaan warna kain mori pada pewarnaan dengan zat pewarna sabut kelapa, (2) tidak ada pengaruh lama waktu mordanting (8 jam, 12 jam, 16 jam) terhadap kekuatan tarik kain mori pada pewarnaan dengan zat pewarna sabut kelapa. Hasil pengujian diatas terjadi karena hasil pewarnaan tidak hanya dipengaruhi oleh mordanting saja tetapi dapat dipengaruhi oleh banyak faktor.
\end{abstract}

Kata kunci: lama waktu mordanting, ketuaan warna, kekuatan tarik kain

\section{PENDAHULUAN}

Pewarnaan bukan istilah yang asing dalam dunia tekstil. Hasil pewarnaan di bidang tekstil diharapkan dapat menghasilkan warna kain yang bervariasi, sehingga dapat menghasilkan berbagai macam warna kain yang menarik. Bahan yang digunakan untuk mewarnai kain dapat

\footnotetext{
* Esther Mayliana, (esther_mayliana@yahoo.com), Staf Pengajar Jurusan Kriya Fakultas seni Rupa Institut Seni Indonesia Yogyakarta
} 
dibedakan menjadi dua, yaitu pewarnaan dengan zat pewarna kimia dan zat pewarna alam.

Zat pewarna kimia diperoleh dari campuran zat kimia yang sudah diolah, contohnya, zat pewarna naptol, indigosol remasol dan lain sebagainya. Zat pewarna kimia memiliki kelemahan dapat merusak lingkungan. Zat pewarna alam diperoleh dari hasil perebusan bahan alam (ekstraksi) sehingga menjadi zat pewarna alam. Zat pewarna alam dapat diperoleh dari bahan alam, seperti: daun, kulit kayu, kayu, akar, buah dan lain sebagainya. Kelebihan zat pewarnaan alam adalah aman bagi lingkungan. Pada penelitian ini sabut kelapa digunakan sebagai bahan zat pewarna karena sabut kelapa merupakan salah satu limbah alam yang mudah didapatkan di seluruh wilayah Indonesia.

Pewarnaan dengan zat warna alam terdiri dari beberapa tahapan yang harus dilalui guna keberhasilan pewarnaan. Tahap Pertama adalah mordanting, yaitu proses awal yang dilakukan sebelum pewarnaan dengan tujuan menghilangkan semua jenis kotoran pada kain sehingga pada proses pewarnaan zat pewarna dapat masuk kedalam serat kain. Proses mordanting dilakukan dengan merendam kain mori kedalam air yang sudah dilarutkan bahan mordan selama 12 jam. Pada penelitian ini digunakan tawas dan soda abu sebagai bahan mordan. Tahap kedua adalah proses pembasahan, yaitu suatu proses yang berfungsi untuk membuka pori-pori kain. Pada penelitian ini digunakan TRO (Turkis Red Oil) sebagai bahan pembasah, proses ini dilakukan selama 5 menit. Tahap ketiga adalah pencelupan kain kedalam zat pewarna, yaitu suatu proses yang bertujuan untuk memberikan warna pada kain, proses pencelupan dilakukan selama 30 menit. Tahap terakhir adalah fiksasi, yaitu tahap yang dilakukan pada akhir proses pewarnaan yang berfungsi untuk mengunci warna supaya warna tidak mudah lepas. Proses fiksasi menggunakan tawas dan dilakukan selama 10 menit.

Berdasarkan tahap-tahap diatas, mordanting merupakan tahap pertama yang cukup lama dibanding tahap-tahap yang lain, oleh karena itu penelitian tentang lama waktu mordanting perlu dilakukan untuk mengetahui waktu yang efektif tanpa mengurangi fungsinya.

Penelitian ini merupakan penelitian eksperimen yang dilakukan untuk mengetahui ketuaan warna dan kekuatan tarik kain mori pada pewarnaan dengan zat warna sabut kelapa dengan lama waktu mordanting yang berbeda. Variabel bebas dari penelitian ini adalah variasi dari lama waktu mordanting yaitu 8 jam, 12 jam, 16 jam, variabel terikat adalah ketuaan warna dan kekuatan tarik kain mori.

Prosedur Eksperimen: 


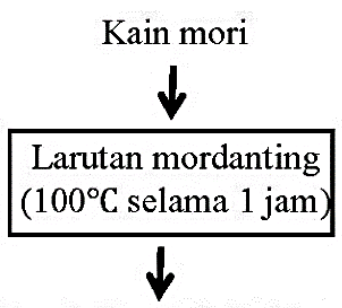

Panci diangkat dari kompor dan kain direndam dalam larutan mordanting pada suhu kamar selama:

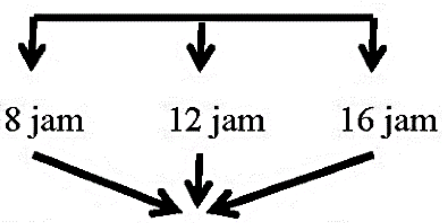

Kain mori diangin-anginkan

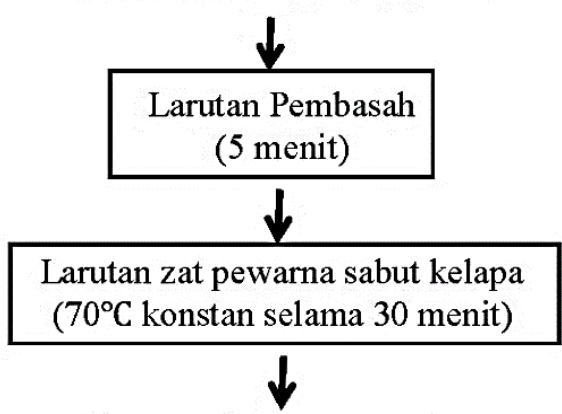

Kain mori diangin-anginkan

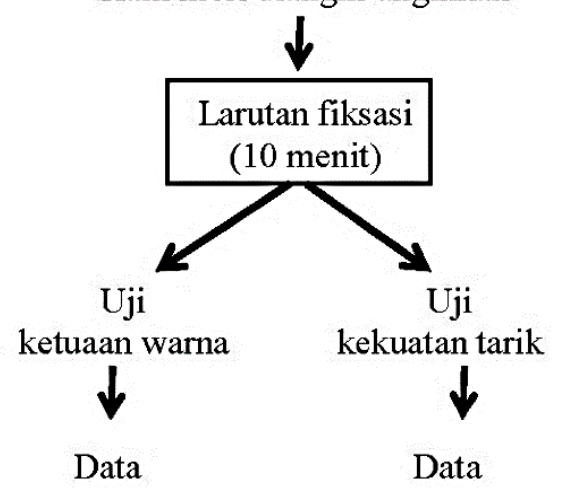

Pengujian ketuaan warna dan kekuatan tarik dilakukan sebanyak 5 kali dan dicari reratanya, kemudian dianalisa statistik dengan menggunakan anava satu jalur.

\section{HASIL PENELITIAN}

Hasil uji ketuaan warna kain mori, pada pewarnaan dengan zat pewarna sabut kelapa yang telah dimordanting dalam waktu yang berbeda menghasilkan data sebagai berikut:

\begin{tabular}{cccc}
\hline Ulangan & \multicolumn{3}{c}{ Mordanting } \\
\cline { 2 - 4 } & 8 jam & 12 jam * & 16 jam \\
\hline 1 & 1,1250 & 0,9557 & 0,9436 \\
\hline 2 & 1,0062 & 1,0259 & 0,9805 \\
\hline 3 & 1,0259 & 1,1712 & 1,0062 \\
\hline 4 & 1,0394 & 1,0955 & 1,0062 \\
\hline 5 & 0,8801 & 1,0883 & 1,2282 \\
\hline Rerata & $\mathbf{1 , 0 1 5}$ & $\mathbf{1 , 0 6 7}$ & $\mathbf{1 , 0 3 3}$ \\
\hline
\end{tabular}

Pengujian dengan Spectrophotometer merupakan pengujian berdasarkan cahaya (sinar) dari sumber yang dipantulkan oleh kain. Reflektan/pantulan yang dilambangkan dengan R\%, kemudian R\% terkecil dikonsultasikan dengan tabel $\mathrm{K} / \mathrm{S}$ untuk mengetahui ketuaan warnanya. R\% terkecil diambil karena untuk pengukuran ketuaan warna dicari warna yang mendekati warna gelap.

Kekuatan tarik diuji dengan Tenso Lab dengan prinsip kerja memberikan beban maksimal pada sampel uji sehingga sampel uji tersebut putus. Komputer secara otomatis akan menghitung nilai rata-ata beben maksimal yang membuat sampel uji putus. Hasil uji kekuatan tarik kain mori:

\begin{tabular}{cccc}
\hline Ulangan & \multicolumn{3}{c}{ Mordanting } \\
\cline { 2 - 4 } & 8 jam & 12 jam * & 16 jam \\
\hline 1 & 21,600 & 17,799 & 20,899 \\
\hline 2 & 20,000 & 17,399 & 20,600 \\
\hline 3 & 22,799 & 20,700 & 22,299 \\
\hline 4 & 19,899 & 18,799 & 19,500 \\
\hline 5 & 19,100 & 20,399 & 22,299 \\
\hline Rerata & $\mathbf{2 0 , 6 8 0}$ & $\mathbf{1 9 , 0 1 9}$ & $\mathbf{2 1 , 1 1 9}$ \\
\hline
\end{tabular}

Pengujian analisis data dilakukan untuk mengetahui apakah data yang digunakan tersebut memenuhi asumsi dari 
penggunaan analisis varian atau belum. Pengujian normalitas menggunakan chi Kuadrat sedangkan pengujian homogenitas menggunakan uji C-Cochran.

Uji Normalitas ketuaan warna :

$\begin{array}{ll}\mathrm{db} & : 9 \\ \text { Simpangan baku } & : 0,090 \\ \text { Rerata } & : 1,039 \\ \text { Chi Kuadrat } & : 3,100 \\ \text { Tabel Chi Kuadrat (5\%) } & : 16,919\end{array}$

Hasil ringkasan diatas menunjukkan bahwa sebarannya normal, karena Chi Kuadrat hitung $(3,100)<$ Chi Kudrat tabel $(16,919)$.

Uji normalitas kekuatan tarik kain mori:

$\mathrm{db}$

Simpangan baku

Rerata

Chi Kuadrat

Tabel Chi Kuadrat (5\%) : 16,919

Hasil ringkasan diatas menunjukkan bahwa sebarannya normal, karena Chi Kuadrat hitung $(5,421)<$ Chi Kudrat tabel $(16,919)$.

Uji Homogenitas dengan C-Cochran menunjukkan bahwa varian untuk setiap pasangan perlakuan pada variabel ketuaan warna dan kekuatan tarik kain mori dinyatakan homogen.

Data yang diperoleh dari hasil pengujian kemudian dianalisis uji statistik dengan varian satu jalur. Taraf siginifikansi atau taraf kesalahan yang dietetapkan adalah $5 \%$.

Ringakasan anava satu jalur ketuaan warna:

\begin{tabular}{ccccccc}
\hline $\begin{array}{c}\text { Sum } \\
\text { ber }\end{array}$ & JK & d & RK & F & $R^{2}$ & P \\
\hline Anta & 0,0 & 2 & 0,0 & 0,3 & 0,0 & 0,6 \\
r A & 07 & & 03 & 90 & 61 & 90 \\
& & 1 & & & & \\
Dala & 0,1 & 2 & $0 ., 0$ & - & - & - \\
m & 08 & & 09 & & & \\
\hline Total & $\mathbf{0 , 1}$ & $\mathbf{1}$ & - & - & - & - \\
& $\mathbf{1 5}$ & $\mathbf{4}$ & & & & \\
\hline
\end{tabular}

Nilai $F_{\text {Hitung }}$ ketuaan warna adalah 0,390. Harga $F_{\text {Hitung }}$ selanjutnya dikonsultasikan dengan $F_{\text {Tabel }}$ dengan db pembilang 2 dan $\mathrm{db}$ penyebut 12 , taraf signifkan $5 \%$ diperoleh harga 3,88 . Dari data tersebut dapat dilihat bahwa $F_{\text {Hitung }}(0,390)<$ $F_{\text {Tabel }}(3,88)$, sehingga dinyatakan tidak signifikan. Jadi tidak terdapat pengaruh yang signifikan lama waktu mordanting terhadap ketuaan warna kain mori.

Ringkasan anava satu jalur kekutan tarik kain mori:

\begin{tabular}{clccccc}
\hline Sumber & $\mathrm{JK}$ & $\mathrm{db}$ & $\mathrm{RK}$ & $\mathrm{F}$ & $R^{2}$ & $\mathrm{P}$ \\
\hline Antar A & 12,269 & 2 & 6,134 & 3,130 & 0,343 & 0,080 \\
& & & & & & \\
Dalam & 23,519 & 12 & 1,960 & - & - & - \\
\hline Total & $\mathbf{3 5 , 7 8 8}$ & $\mathbf{1 4}$ & - & - & - & - \\
\hline
\end{tabular}

Nilai $F_{\text {Hitung }}$ kekuatan tarik kain mori adalah 3,130. Harga $F_{\text {Hitung }}$ selanjutnya dikonsultasikan dengan $F_{\text {Tabel }}$ dengan db pembilang 2 dan $\mathrm{db}$ penyebut 12 , taraf signifkan 5\% diperoleh harga 3,88. Dari data tersebut dapat dilihat bahwa $F_{\text {Hitung }}$ $(3,130)<F_{\text {Tabel }}(3,88)$, sehingga dinyatakan tidak signifikan. Jadi tidak terdapat pengaruh yang signifikan lama waktu mordanting terhadap kekuatan tarik kain mori.

\section{PEMBAHASAN}

Sifat dasar yang diinginkan dari kain diantaranya adalah kekuatan tarik yang sedang dan daya tarik terhadap zat warna yang baik (Hartanto dan Watanabe, 1980) Pada proses pewarnaan, kain bereaksi terhadap zat-zat yang digunakan, baik itu zat mordanting, zat warna maupun zat fiksasi, akibat dari reaksi tersebut terjadi perubahan pada sifat serat.

Hasil Pengujian dipengaruhi oleh banyak faktor, diantaranya:

1. Bahan Mordan 
a. Menurut

http://amsor.com/usingdyes.htm, serat kain akan meneruskan penyerapan bahan mordan saat temperatur pada suhu kamar. Pada pernyataan ini tidak ditunjukkan seberapa besar bahan mordan yang dapat diserap oleh kain, jadi dapat diasumsikan bahwa sedikitnya bahan mordan yang dapat terserap oleh kain sehingga menyebabkan sedikit mempengaruhi hasil mordanting.

b. Reaksi soda abu menurut Susanto (1980) berfungsi untuk mengatur kerataan hasil celupan dan tidak membuat kain menjadi semakin bersih. Hal ini dapat pula mempengaruhi hasil penelitian karena bahan mordan tidak membuat kain semakin bersih, tetapi membuat kain menjadi stabil sehingga kerataan tercapai.

2. Zat pewarna sabut kelapa

Derat sabut kelapa menggandung komposisi bahan organik tidak larut dalam air (Siti Fadilah, 2001), bahan tersebut diasumsikan berupa minyak, sehingga kain menjadi kotor kembali setelah proses pewarnaan.

3. Fiksasi

Bahan fiksasi yang digunakan adalah tawas, bahan ini bereaksi mengikat zat warna yang terserap pada kain setelah proses pencelupan. Jadi hasil pewarnaan sangat dipengaruhi oleh fiksasi, karena pada tahap ini jumlah zat warna yang diikat akan menentukan hasil pewarnaan.

Faktor-faktor diatas menunjukkan bahwa bahan yang digunakan selama proses pewarnaan dapat mempengaruhi hasil pewarnaan, sehingga diperoleh hasil yang tidak signifikan.
Hasil pengujian kekuatan tarik menunjukkan hasil yang tidak signifikan pada kain mori. Kain mori dibuat dari serat kapas, menurut Soeprijono dkk (1974), kekuatan serat kapas dipengaruhi oleh kadar selulosa dalam serat, panjang rantai dan orientasinya. Komposisi kimia serat kapas, yaitu:

\begin{tabular}{lc}
\hline \multicolumn{1}{c}{ Konstitusi } & $\begin{array}{c}\text { \% terhadap berat } \\
\text { kering }\end{array}$ \\
\hline Selulosa & 94 \\
\hline Protein (\%Nx6,25) & 1,3 \\
\hline Pektin & 1,2 \\
\hline Lilin & 0,6 \\
\hline Abu & 1,2 \\
\hline Pigmen dan zat lain & 1,7 \\
\hline
\end{tabular}

Diatara zat bukan selulosa yang menyusun serat, pektin merupakan zat penting. Pektin adalah karbohidrat dengan berat molekul tinggi dan struktur rantainya seperti selulosa. Pektin akan hilang dalam proses pemasakkan kapas dengan larutan natrium Hidroksida ( $\mathrm{NaOH}$ ) (Soeprijono dkk, 1974). Soda abu $\left(\mathrm{Na}_{2} \mathrm{CO}_{3}\right)$ merupakan bahan yang digunakan untuk pembuatan $\mathrm{NaOH}$. Pada proses mordanting menggunakan larutan soda abu, jadi pada proses ini pektin pada serat kapas hilang, tetapi proses penghilangan pektin tidak banyak mempengaruhi kekuatan maupun kerusakan serat kapas (Soeparijono dkk, 1974). Jadi dapat disimpulkan bahwa mordanting tidak mempengaruhi kekuatan tarik serat kain, karena proses mordanting tidak menyebabkan kerusakan pada serat.

\section{PENUTUP}

\section{Kesimpulan}

Berdasarkan penelitian ini dapat disimpulkan bahwa zat pewarna sabut kelapa menghasilkan warna coklat muda, perbedaan lama mordanting yaitu 8 jam, 12 
jam dan 16 jam tidak mempengaruhi ketuaan warna pada kain mori.

Kekuatan tarik kain mori pada hasil pewarnaan dengan zat pewarna sabut kelapa dengan lama waktu mordanting 6 jam, 12 jam, dan 18 jam dapat dikategorikan kekuatan tariknya baik dan tidak ada perbedaan kekuatan tarik yang signifikan pada ke tiga kain mori tersebut.

\section{Saran}

- Penggunaan bahan alam yang dimanfaatkan untuk zat pewarna saat ini masih terbatas, oleh karena itu perlu diadakan eksperimen lebih lanjut tentang penggunaan bahan alam sebagai zat pewarna.

- Penelitian ini menggunakan sabut kelapa yang berasal dari jenis kelapa hijau yang sudah tua sebagai bahan alam penghasil warna, sehingga menghasilkan warna coklat muda. Penggunaan jenis kelapa yang lain sebagai bahan penghasil warna belum diketahui hasilnya, oleh sebab itu perlu dikembangkan penggunaan sabut kelapa jenis lain sebagai bahan pewarna.

- Penelitian ini menunjukkan hasil yang tidak signifikan antara pengaruh lama waktu mordanting terhadap ketuaan warna dan kekuatan tarik, untuk itu perlu dilanjutkan dengan pengujian pengaruh lama waktu mordanting terhadap kerataan warna pada pewarnaan kain mori dengan menggunakan zat pewarna alam, menginat fungsi dari mordanting untuk meratakan hasil pewarnaan.

- Penelitian ini menunjukkan hasil yang tidak signifikan antara pengaruh lama waktu mordanting terhadap ketuaan warna, hal ini disebabkan karena ketuaan warna dipengaruhi oleh fiksasi, untuk itu perlu dilakukan penelitian lebih lanjut tentang pengaruh fiksasi terhadap ketuaan warna.

\section{DAFTAR PUSTAKA}

Ballmeyer F.W and Saltman M. Principles of Colour Technology New York: Interscience Publisher Division Of John Wiby and Son's

Chariono, N. (1996) Teori dan Aplikasi Penandingan Warna dengan Spektrofotometer. Bandung Institut Teknologi Tekstil

Chatib, W. Dan Soenaryo, O. (1979). Pentunjuk Praktek Pengujian Tekstil Jilid 1. Jakarta: Depatemen Pendidikan dan Kebudayaan.

Chatib, W. Dan Soenaryo, O. (1980) Teori Penyempurnaan Tekstil Jilid 2, Jakarta: Depatemen Pendidikan dan Kebudayaan.

Djufri, R. (1973). Teknologi Pengelantangan, Pencelupan dan Pencapan. Bandung: Institut Teknologi Tekstil.

Fadilah, S. (2001). "Pengaruh Konsentrasi Zat Pemutih Terhadap Perubahan Warna dan Daya tarik Serat Buah Kelpa sebagai Bahan Kerajinan". Skripsi. Yogyakarta: Universitas Negeri Yogyakarta.

Gasperz, V. (1991). Teknik Analisa Dalam Penelitian Percobaan. Bandung: Tarsito.

Hadi, S. (1968). Statistik Jilid 3. Yogyakarta: Yayasan Andi Offset.

Hasanudin, M. Dkk (2001). "Penelitian Penerapan ZWA dan Kombinasinya Pada produk Batik dan Tekstil Kerajinan". Hasil Penelitian. 
Yogyakarta: Balai Pengembangan dan PelayananTteknologi Indstri Kerajinan dan Batik

http://amsor.com/usingdyes.htm

Jumaeri, dkk. (1977). Pengetahuan Barang Tekstil. Bandung: Institut Teknologi Tekstil.

Musa, M. (1983). Petunjuk Pelaksanaan Blok Penghasil Tinggi Kelapa Dalam. Bogor: Balai Penelitian Tanaman industri Bogor.

Natsir, M.A. (2001). Kamus Kimia. Jakarta: PT. Gramedia Pustaka Utama.

Oriyati. (1982). Teori Penyempurnaan Tekstil 3. Jakarta: Direktorat Pendidikan Menengah Kejuruan.

Poerwodarminto. (1993). Kamus Besar Bahasa Indonesia. Jakarta: Balai Pustaka

Soeprijono, P. (1974). Serat-Serat Tekstil. Bandung : Institut Teknologi Tekstil

Sugiarti, N.H. dan Watanabe, S. (1980). Teknologi Tekstil. Jakarta: PT. Pradnya Paramita.

Sugiyono (1997). Statistika untuk Penelitian. Bandung: Alfabeta.

Suhardiyono, L. (1993). Tanaman Kelapa, Budidaya dan Pemanfaatannya. Yogyakarta: Kanisius.

Sunoto, R. (1993). Diktat Membatik. Yogyakarta: FPTK IKIP

Susanto, S. (1980). Seni Kerajinan Batik Indonesia. Yogyakarta: Balai Pengembangan Kerajinan dan Batik.

Tim Penyususn Balai Besar Penelitian dan Pengembangan Industri Tekstil, Standar Industri Indonesia (SII) 010675. Yogyakarta: Balai Pengembangan Kerajinan Batik. www. Techno-preneor.net. 